\title{
Discussion Surrounding the Identification of Henry IV's Alleged Skull
}

Riaud Xavier ${ }^{1 *}$, Delorme Philippe ${ }^{2}$ and Lorin de la Grandmaison Geoffroy ${ }^{3}$

${ }^{1}$ Doctor of Dental Surgery, Doctor of Epistemology, History of Sciences and Techniques, Laureate and National Associate Member of the National Academy of Dental

Surgery, Free Member of the National Academy of Surgery, Saint Herblain, France

${ }^{2}$ Historian, Independent Researcher, Versailles, France

${ }^{3}$ Department of Forensic Medicine and Pathology, Raymond Poincaré Hospital, Garches, France

\begin{abstract}
On Sunday March $13^{\text {th }} 2011$, at half past eight in the evening, the French public national television channel France 5 broadcast a documentary relating the investigation which had led to the "formal" identification of Henry IV's skull. It had been conducted by a team of scientists led by Doctor Philippe Charlier, a forensic medical examiner-a well-known anthropologist.

Throughout the programme, many factors were introduced and proved the identification. And yet, taking a scientific step back and looking at things from a distance with historical knowledge, these factors seem to be questionable. Here is a new perspective which showed the seeds of doubt on the showcasing of absolute certainty.
\end{abstract}

Keywords: Forensic medicine; History; Skull; Henry IV

\section{Introduction}

On Sunday March $13^{\text {th }} 2011$, at $8.30 \mathrm{pm}$, the French public national television channel France 5 broadcast a documentary relating the investigation which allegedly had led to the "formal" identification of Henry IV's skull. It had been conducted by a team of scientists led by Doctor Philippe Charlier, a forensic medical examiner-a well-known anthropologist. Throughout the programme, many factors were introduced and proved the identification. In the foreground, Doctor Philippe Charlier was playing the lead role as an investigator, with a voice over which intended to develop the arguments with a little suspense. In spite of all, inconsistencies appeared quickly. In 2012, the same documentary was broadcast on the same channel, this time introduced by one of the authors, the journalist Stéphane Gabet, close collaborator of Doctor Charier. Some time later, in February 2013, both men even published a book together on this matter. Each time, arguments were presented, then developed, through media language which seems consistent, as a police investigation for all audiences, leading inevitably to identifying Henry IV's skull... according to the authors.

And yet, taking a scientific step back and looking at things from a distance with historical knowledge, these factors seem to be questionable. A new perspective which sowed the seeds of doubt on the showcasing of absolute certainty. The objective of this study is to provide an exhaustive counter-argument which does not intend to be polemical.

\section{The Actors}

Doctor Philippe Charlier is a university lecturer and researcher at the Laboratory of medical ethics at Paris V University. Until September 2013, he was an hospital practitioner in the department of forensic medicine at Raymond Poincaré university hospital in Garches, France. Today, he manages a multidisciplinary team working on anthropology, paleopathology, and pathography. He also manages the "Pathographies" Collection at the De Boccard Editions. He received an award from the French Academy and the National Academy of Medicine for two of his books, and worked particularly on the alleged remains of Agnès Sorel, of Fulk III of Anjou, of Diane de Poitiers, on false relics of Joan of Arc and on the alleged head of Henry IV.
Stéphane Gabet is a journalist, former editor-in-chief of the programme called "Secrets d'Histoire" and current editor-in-chief at Galaxie Presse.

These two men published several major articles on this matter:

- A documentary entitled The mystery of Henry IV's head, Galaxie Presse, Meeting of National Museums, 2011, broadcast on France 5.

- Charlier P et al. [1]: Multidisciplinary medical identification of a French king's head (Henri IV)

- Charlier P et al. [2]: Genetic comparison of the head of Henri IV and the presumptive blood from Louis XVI (both Kings of France).

- Charlier $\mathbf{P}$ et al. [3]: La tête momifiée d'Henri IV. Une identification médico-légale.

- Charlier P et al. [4]: Henri IV, l'énigme du roi sans tête, Vuibert (éd.) : 156

and many others which are less important

\section{Historical rationale}

23 arguments (24 if we consider the whole route this relic took) have been presented, formally identifying the skull as Henry IV's, or at least, with a probability "above 99.9\%" according to Gabet and Charlier [4].

Which facts have been historically proven? In 1610, Henry IV's body was placed into the crypt of Saint-Denis Basilica. The coffin was desecrated in 1793 during revolution's pillages. In 1919, a certain Joseph

*Corresponding author: Riaud Xavier, Doctor of Dental Surgery, Doctor of Epistemology, History of Sciences and Techniques, Laureate and National Associate Member of the National Academy of Dental Surgery, Free Member of the National Academy of Surgery, Saint Herblain, France, Tel: 0240766488; E-mail: xavier.riaud@wanadoo.fr

Received November 06, 2013; Accepted January 06, 2014; Published January 23, 2014

Citation: Xavier R, Philippe D, Geoffroy LG (2014) Discussion Surrounding the Identification of Henry IV's Alleged Skull. J Forensic Res 5: 212. doi:10.4172/21577145.1000212

Copyright: (c) 2014 Xavier R et al. This is an open-access article distributed under the terms of the Creative Commons Attribution License, which permits unrestricted use, distribution, and reproduction in any medium, provided the original author and source are credited. 
Emile Bourdais, convinced it was Henry IV's, bought an anonymous skull for 3 francs during an auction. When he died in 1946, his sister, Mrs Gaillard, inherited the relic which then disappeared without leaving a trace. It had been bought to Mrs Gaillard by a certain Jacques Bellanger, from Châteaudun. M. Bellanger will later write on that matter to the historian Jean-Pierre Babelon. In 2010, this latter will tell the journalists Stéphane Gabet and Pierre Belet about it, to whom $\mathrm{Mr}$ Bellanger will lend his "relic" in order to analyse it.

\section{A few notes are required}

There is no direct source testifying of the disappearance or the sampling of the head of Henry IV's cadaver during Saint-Denis profanations. Yet, many people witnessed his exhumation. On the contrary, they all certify that the whole body was thrown into a mass grave on October 14th 1793, with the remains of other Bourbons, and then recovered with soil and lime. Nevertheless, Charlier and Gabet [4] present as a certainty "the dismantling of the head from the body by a revolutionary in 1793 , as a deliberate mutilation". They even say: "Eventually, we can say with near-certainty that the head was separated from the rest of the body using a bladed weapon, presumably a knife or a sabre, at least a well-sharpened tool. We see quite clearly that the section plane is at the lower extremity of the neck, between two vertebrae."

Where are the testimonies and historical documents supporting that such an operation would have been performed on Henry IV's mummy? There are none. Only one testimony reports that a soldier used his sabre to cut the king's moustache.

Unaware of when and how the king's head could have been stolen, both authors estimate, without historical evidence, simply asserting, that Alexandre Lenoir, founder of the museum of French Monuments, would have stolen this skull. What evidence is there? Indeed, there will be a genuine trafficking operation of relics from various exhumations performed under the Reign of Terror. Turenne's, Voltaire's, and even Molière's teeth were part of this macabre deal. Actually, Alexandre Lenoir would have removed a few royal relics during exhumations. They are in a box returned to Saint-Denis in 1898. Here are the bones, whose origins yet remain doubtful:

- Hugh Capet's scapula;
- Charles V's femur;
- Charles VI’s shin bone;
- Charles VII's vertebra;
- Charles IX's vertebra;
- Philip IV's rib;
- Louis XII's rib;
- Catherine de Medici's lower jaw;
- Cardinal de Retz's shin bone.

Besides, Lenoir's collections are famous and listed. There is no skull [5].

Finally, how could he have stolen it, risking his life during this very troubled period, under the nose of the revolutionaries watching your every move? And above all, why wouldn't he return this noteworthy relic to Louis XVIII, under the Restoration, which would have made him a courageous royalist hero?

And admitting even this very unlikely eventuality of steaming
Henry IV's head at Saint-Denis, what would it have become between 1793 and 1919? We shall bear in mind that there is no testimony of the dismantling of the head from the body, or of what it could have become later.

\section{Scientific rationale}

Thus there are 23 scientific arguments [4]. Four end up with interrogation marks, leaving a doubt. None brings a formal evidence of identification. Only six rely on a comparison with elements from various origins. But these origins, are they reliable?

Arguments 1, 3, 4: Male, leucoderm (white skin), anthropologically Caucasian person [4].

These are very common physical characteristics. In no case are these evidences, or arguments in favour of an identification. The authors of this article - as well as several billions of persons throughout the ages share these characteristics... without varying royal blood.

Argument 2: Mature adult age. Dead at 57 years old [4].

Age has not been clearly defined. The adjective "mature" does not give any indication about the exact age of the relic. Neither is there a standard deviation. This is just a vague observation. Here again, this is not an evidence. No tooth remains on the skull to perform an effective dating. (Ex: Ramesses II's mummy ( \pm 80 years old using Gustafson's method)).

Argument 5: Very poor bucco-dental status. Several teeth lost antemortem [4].

Henry IV's poor dentition is well known. And so are his repeated inflammations. A decree from Richelieu will blunt the lords' daggers, thus inventing knives with rounded blades. The cardinal was tired of watching his banquets' guests picking their teeth with the tip of their knives, which clearly illustrates the fillings caused by dental caries and the poor bucco-dental status of people back then. Henry IV is not an isolated case. Sugar appeared at the French court with Marie de Medici's pastrycooks. Louis XIII loved baking cakes and also had serious dental issues [6]. In his broadcast documentary, Philippe Charlier presents a tooth preserved at Tavet-Delacour Museum (Pontoise, France) as being one of Henry IV's. The skull Bourdais had bought had lost the 28 and 38 after death. This tooth is an 18. It is wrapped with a golden thread. This prosthetic artefact would be dated back to the first half of the $\mathrm{XX}^{\text {th }}$ century, according to Charlier himself $[7,8]$. However, it is presented as being one of Henry IV's tooth in the documentary. Some contemporary with Henry IV (Henry III, Diane de Poitiers) were known to carry dental prostheses (golden thread+tooth). They are often mocked for this reason in satirical poems or various chronicles [9]. Jean-Pierre Babelon, in his Henry IV [10], reports an accountancy from 1576 which mentions 20 sols per month for "toothpicks in lentisk wood" for the Navareese King's use. In 1581, the register of the Accounting Chamber of Pau, France, reports the Finance Minister received 15 sols for "gold to plumb the King's teeth". Similarly, Mr Pierre, a surgeon, received a cautery of gold which is worth 5 crowns and the making, 15 sols. In 1576, Henry is at the castle of Nérac, with his first wife, Margaret de Valois. In order to please him, "he stocks up on gold powder to make his teeth brighter and his smiles more irresistible [10]".

From 1579 to 1582 , purchases of gold to fill teeth prove the future Henry IV had received dental care. These purchases slowed down a little after Margaret de Valois' departure, around 1582 [11]. If JeanPierre Babelon could find such archives, how did he find nothing on a dental prosthesis? Besides, Pontoise's tooth does not correspond to any 
of the tooth sockets on Bourdais' skull. The authenticity of this tooth remains highly questionable.

Argument 6: Red hair with canities (partial white hair) histological confirmation. Additional red pigment after death related to the lead from the coffin.

\section{Argument 7: Hair cut short/broken [4].}

Bourdais's head is almost bald and hairless. Even if hair samples were made by Alexandre Lenoir-as he recognises himself-or by other revolutionaries, they do not explain why the skull is completely hairless. The mummy's drawing made by Lenoir in 1793, during the profanation, shows without question, abundant hair and beard. Besides, according to him, these samples were "small". Young Henry IV had red-blond hair. Old, all the portraits represent him with grey or white hair. Not red [9].

Argument 8: Presence of lead residues revealing a prolonged stay in a lead container [4].

Can this argument be considered as a reference? Indeed, was Henry IV's body the only one to be buried into a leaden coffin? The answer seems obvious to me: it was a common practice for princes but also for important people [9].

Argument 9: Isotopic homogeneity between Pontoise's and the head's samples [4].

Throughout the documentary, Doctor Joël Poupon, a toxicologist biologist at Lariboisière Hospital in Paris, France, explains to Doctor Charlier that the samples of the skull and of various relics from TabetDelacour museum attributed to Henry IV "have all the same isotopic profile, and most likely the same source and the same lead origin." The results of those experiment are strangely absent from the British Medical Journal's article and, in the Supplementary material, Doctor Charlier seriously moderate his enthusiasm on TV: "Elementary analyses have been performed on samples of the skull and of Henry IV's relics from Pontoise. They revealed the presence of important quantities of lead in most samples, probably coming from a leaden coffin used back then to bury aristocratic people. The fact that lead compounds produced by the coffin's degradation are deposited on the remains is a well-known osteoarcheological phenomenon. Isotopic ratios for lead were highly similar within and between both groups (head and Pontoise's samples), with the margin of error overlapping (two standard deviations). That is why we can only conclude both lead sources have a similar isotopic composition $[1,7]$."

After having examined the Supplementary material above mentioned, Professor Eric Marcoux from the Institute of Earth Sciences at Orléans University shows a certain conviction. He is for instance the author of Lead isotopes and metallic parageneses, tracking history of mineral deposits [...] Orléans, Editions of the Bureau of Mines and Geological Researches, 1987 [8].

"There is actually no result mentioned about Pb isotopic geochemistry, only the conclusion that "both sources of lead are identical", but no data supports this statement. In these conditions, you have to take the author's word for it. Unless in this type of historical article, which I do not know well, it is unnecessary to state all the very technical results. Anyway, I can give you the following elements. Isotopic measures were performed by an ICP/MS quadrupole, a very powerful device but (for now) less accurate than the TIMS (mass spectrometry) regarding isotopic measures. The uncertainty given by the authors for the ICP/MS is of 0.19 at $0.50 \%$, which is very good for this type of method, but for isotopic measures, it is 5 to 10 times better with the TIMS. The authors report an isotopic similarity by 2 SDs (i.e. 0.38 by 1\%). Due to slight isotopic differences in France between the different mines (the usual 206Pb/204Pb ratio varies from 18.20 to 18.60), this uncertainty is too important to establish reliable relationships between two or several samples. To conclude, the absence of published isotopic ratios is highly detrimental and does not provide a clear opinion on the reliability of the authors' conclusions. Personally, I am very sceptical since the method of lead isotopic geochemistry seems ill-suited to establish the very subtle relationship they expected. First, the isotopic signature of lead is absolutely not specific to one person, and if it were, the analytical method is not accurate enough to strongly support other more relevant methods exposed in the article, but which I cannot assess $[7,8] . "$

Argument 10: Hyperpigmented skin lesion on the right nostril. Lesion certified on many portraits, sculptures, and examples of funerary masks (nevus) [4].

Some portraits are actually showing a nevus ( 7 according to Charlier), but many others do not. Our of the 38 portraits on Gallica website, a numerical library of the Bnf (French library), only one shows a nevus. Besides, the funerary mask of Sainte-Geneviève's library, moulded on the king's cadaver the very next day after his death, does not show any nevus, whereas other very accurate details are represented $[7,8]$.

Argument 11: Former maxillary bone scar. Trauma related to the attempted murder using edged weapon by Jean Châtel on December 27th, 1594? [4].

Regarding the palatine bone scar, no text which mentions Jean Châtel's attack on December 27th, 1594 mentions a bone penetration of the knife's blade. Thus, Pierre de l'Estoile reports: "The stab concerned the upper lip on the right and cut a tooth [12]." Henry IV himself reports this aggression in the official letters sent the day of the attack to the cities of the kingdom, to reassure about his condition. "... A young boy, named Jean Châtel, (...) walked up almost without being noticed and thought he could stab us with his blade; the stab reached only the upper lip on the right and cut one of our teeth since we had bent down to lift up $\mathrm{Mr}$ de Ragny and Mr de Montigny who were bowing [10]..."

To sum up, the blade was supposed to reach the neck, but Henry IV moved, which means the author had no time to correct his gesture. Thus, he reaches the mouth at the end of his stab. He cuts the upper lip. On January 5th, 1595, according to Jean-Pierre Babelon, Henry IV is still seen with a plaster on his mouth. The stab was however violent enough to explode a central incisor. It is mentioned nowhere that the blade penetrated the bone, which would have resulted into a more serious more damaging wound. In this case, would the king have had enough force to write to the cities the same day or the following days? Besides, where is on the presented bone the alveolus with the root of the fractured incisor, which might still be into the maxillary bone [9]?

Charlier himself wonders: "First, does the scar on the lip really exist on this mummy? [...] What Henry IV does not say but what one of his counsellors reports, Pierre de l'Estoile, is that his surgeon tried to suture him with 2 stitches. But the first was so painful that he refused the second and kept until his death an ugly scar. [...]"

According to Charlier again: "Joseph Emile Bourdais, the antique dealer, thought he was seeing the mark of this wound on the right upper lip. But with a binocular magnifier, at this place, there is nothing, except a small fold and a large section of the skin at the lateral face of the neck. It has nothing to do with a wound, Bourdais was mistaken: this is a trace of the decapitation, well after the person's death [1]."

Since there was nothing on the right, Charlier looks at the other side 
of the face. He sees a lesion on the left hemi-maxillary bone (reported in the British Medical Journal) [7,8]. However, as we said, Henry IV himself testifies he has been wounded at the right upper lip [12].

Argument 12: Pierced right ear lobe. Right earring certified at least by one portrait preserved in Chantilly museum [4].

In the broadcast documentary, Jean-Pierre Babelon himself-who knows Henry IV better than anyone-recognises his puzzlement about this pierced ear, then he says: I think no portrait, unless I am mistaken, no portrait represents him with earrings". Indeed, almost all the paintings, carvings, and statues representing Henry IV have no earring ornament [9]. Thus, Gallica website presents 16 carved portraits of Henry IV from the XVIth century and 22 from the XVIIth century $[7,8]$. None shows the king with an earring. Even during his semi-captivity at the French court, between 1572 and 1576, the young Navareese King does not seem to yield for this trend. Henry III had one [9]. Charlier and Gabet disclose a carving from the properties of the Condé museum of Chantilly [4]. Yet, this imaginative work by the carver Jean Ganière (ca. 1615-1666) is clearly subsequent to the king's murder. This carving belongs to the same series as those of the King Charles I of England and to his wife Queen Hentietta Maria, dating from 1635-1640 and marked as well of "Ganiere excudit [Ganière made it] [7,8]."

Mrs Nicole Garnier-Pelle, general heritage curator in charge of Condé museum, says: Of all our collections with several tens of Henry IV's portraits, pictures as well as drawings or sculptures, and 59 carvings (...), I only know of one carving where he wears an earring, it is the one I showed [in Belet and Gabet's documentary], the engraving P-352, published by Ganière, but it was most likely not made according to the model and is not an evidence that the king wore an earring; this trend may have been reproduced by the carver on his own $[7,8]$.

Thus, hundreds and hundreds of portraits represent Henry IV without any earring. A research in the alcove of a museum displayed a unique lithography of our king with an earring, which was described right away as an evidence To be so, there should have been an equivalent proportion of portraits representing him with and without this ornament. Yet, it is not so. Could it rather be an extravagance from an author who wanted to stand out and added this jewel to the king [9]?

Argument 13: Corresponding C14 dating. Interval between 1450 and 1640 , for a death which occurred in 1610 [4].

Carbon 14 dating takes into account a standard deviation of 200 years. It is important from an historical point of view and even from a scientific point of view. This interval offers no time accuracy. In 1450 , Charles VII was ruling and in 1640, it was Louis XIII. Two very different period which cannot be compared. Can this argument be taken seriously [9]?

Argument 14: Satisfying anatomical superposition over the funerary mask. Model from Sainte-Geneviève's library;

Argument 15: Satisfying superposition over a portrait by Barthélémy Tremblay (Pau). Sculpture assessed as especially alike by the contemporaries (same points of anatomical comparison) [4].

Regarding the funerary mask, this latter reproduces only the central lines of the face, as Jacques Guillemeau, surgeon in charge of the autopsy report on Henry IV on May $15^{\text {th }}, 1610$ and then of the embalming, explains. He says: "The face is well shaped, [the sculptor] makes and adds the rest of the head, which remains proportional to the actual model. (Les auvres de chirurgie [13])." In his article published in La revue du praticien, Charlier does not report this superposition, since the identification was announced in 2010 [3]. Why?
The marble statue of Henry IV, to which our researcher refers, was made by Barthélémy du Tremblay and finished, after his death in 1629, by his son-in-law, Germain Gissey. Since Henry IV died in 1610, it was finished more than 20 years later [7,8]. Besides, the composite drawing established by Mr Jean-Noël Vignal, police officer, seems very inaccurate. This latter during the documentary asserts it is at best "a doppelganger" [9]. A simple comparison between the composite drawing obtained from Bourdais's head and a painting representing Henry IV, young and beardless, underlines the differences. The eyes on Bourdais's head are too close, the upper lip too full, the jaw too large, whereas the king had a delicate chin-which cannot be seen behind the rounded beard of the old king. Finally, the nose is too short, where the king's was almost falling down to the upper lip, as confirmed by the 1610 mask $[7,8]$. Charlier in his articles published in La revue du praticien admits limits to facial superposition and mentions Professor Franco Ugo Rollo, professor of anthropology at the University of Camerino (Italy), a world-expert in this technique [3].

According to Charlier, "Limits to facial superposition. Since the mouth of the mummified head is open, the comparison of facial superposition could not be completed, as Franco Rollo reported. In practice, we took into account not the 12 regulatory points, but only those of the upper hemiface: shape of the forehead, glabella, roots of the nose's bones, base of the nose, median maxillary position, upper inter-incisor point. Out of these 6 points, the important information in our study was to exclude (or not) the suggested identity. A disagreement (out of 6 and out of 12) would have dismissed this identification [3].

Contacted in 2011, Franco Ugo Rollo reports about this reconstitution: "Comparison between the skull and the funerary mask of the king. The method (Austin-Smith and Maples work, 1994) requires examining 12 anatomical points of the skull (and the head of the person) on its side (norma lateralis) and another 12 points when facing the skull (norma frontalis). Charlier and his colleagues observed the skull only on its side. It would usually mean we have 12 points of comparison [7,8]." According to Professor Rollo, "Here, unfortunately, we do not have the mould of the whole head but only of the face. Besides, the lower jaw of the skull is open, whereas the mask's is tight. All of this means we no longer have 12 points available, but only 3 or 4 between the forehead and the nose. Here, the skin and soft tissues are very thin, thus the skull's profile should follow exactly the mask's profile. Anyone can see this is not the case. The forehead and the nose of the skull do not follow the forehead and the nose of the mask. We can only conclude the skull and the mask belong to two different men $[7,8]$.

"Professor Rollo continues: "We cannot use a statue or a painting to establish the identity of an old skull, since the statue or the painting always results, to a certain extent, from an artist's imagination. Thus, comparing (accurately, of course!) a skull and a statue or a painting always gives a negative result. This is exactly the case with the statue at the Castle of Pau. However, if we have the skull of an historical person whose identity we are $100 \%$ sure of, we can use the skull to check is a portrait (drawing, painting, carving) looks alike or not $[7,8]$." After several experiments superposing the skull and the mask, Professor Rollo (January 16th and February $27^{\text {th }}, 2011$ ) asserts with certainty: I have already done a few superposition experiments which confirmed that mummified skull and mask cannot belong to the same person $[7,8]$."

\section{Argument 16: Satisfying craniofacial reconstruction [4].}

When Henry IV's mummy was removed from the coffin, in 1793, the drawing performed by Alexandre Lenoir shows the mouth was closed. Yet, Philippe Charlier presents a skull with a wide-open mouth 
and adds it would have been opened during the profanation, "to remove some teeth".

"Regarding the open mouth, it falsifies the computed reconstruction and invalidates everything, since the head would have been embalmed with the mouth open. Who can think it is possible to open a dry cadaver's mouth after 183 years? Besides, who has ever seen a plaster funerary mask made on a cadaver with the mouth wide open [7-9]?”

The craniofacial reconstruction was performed by the graphic designer Philippe Froesch, expert in 3D reconstruction, director of Visual Forensic Studio, near Barcelona, Spain. Doctor Jean-Pol Beauthier at the Free University of Brussels (Belgium) underlines the limits of this technique: "All these techniques [craniofacial reconstructive identification] are complex and reserved to specialised laboratories. In fact, the soft tissues' thickness in some anthropological points is not the only difficulty of these methods, for the most important part is the relationship and the balance between the noble parts of the face. Besides, the face shows subtle variations, which make its personality. It is impossible for all skin points to be correctly determined or estimated thanks to anthropological bone points. Finally, we must underline we desperately lack of scientific validations in all these fields: only facial superposition has been studied through elaborate scientific projects. The isolated successes published after facial reconstruction do not prejudice the origin of the success (similarity, opportunity, chance...) and the scientific research must absolutely continue in this field $[7,8,14]$."

If the result is impressive and cannot leave anyone indifferent, can we consider this computed craniofacial reconstruction as scientific evidence?

Argument 17: Presence of bone-black at the base of the neck (pigmentation respecting the face). Charcoal put on the skin of the dead, to absorb cadaverous humours, according to the procedure described by Pierre Pigray, embalmer of Henry IV [4].

The surgeon Pierre Pigray does not evoke using "bone-black on the skin except the face, to absorb the cadaverous humours." And certainly not in his Epitome proceptorum medicinoe chirurgice, published 2 years after the king's death [15]. He never talks about "bone-black", i.e. obtained through carbonizing animals' bones. However, it seems that "the filtered and sieved ashes" he reports come from plants. But, using wood ashes in the embalming procedure is not specific to Pigray. As all the written reports back then from other surgeons, and especially Jacques Guillemeau, Pigray recommends to sprinkle "inside and out" a balm made of myrrh, aloe, birthworts, orris, etc., before wrapping the cadaver into an oil-cloth. No author ever recommends using animal ashes. On the contrary, it is always recommended to use herbs or spices in addition to mineral like lime, sand, plaster, alum, or salt. This black trace at the base of the neck seems to exclude a royal origin for this relic. Nowhere is it said that Pigray was the exclusive embalmer of Henry IV. But, present during the autopsy and the embalming of Henry IV, an so was Jacques Guillemeau, he is the student of Ambroise Paré of whom he follows the precepts. This latter recommends using "slaked lime, and common or oak ashes $[7,8,16]$."

\section{Argument 18: Absence of sawing at the calvaria [4].}

The king's autopsy took place on May $16^{\text {th }}, 1610$, in the presence of 18 physicians and 12 surgeons. Among them, Pigray [15] and Guillemeau [9]. The embalming was performed while they were at it. They both were Ambroise Parés students. Guillemeau recommends two embalming techniques which both require a craniectomy [13]. In the $4^{\text {th }}$ volume of his Epitome proeceptorum medicinoe chirurgioe, Pigray recommends a craniectomy as well: "But the only way is to open the body, empty the venters (upper, lower, and median), and preserve the internal parts aside." The " upper venter » means skull [15].

Embalming techniques including craniectomy according to the procedures of Ambroise Paré were used over the last three centuries of the Former Regime. They were almost systematically applied for descendants or relatives of Henry IV. The last who benefited from these techniques was Louis XVIII in 1824. Regarding a potential "art of the Italians", without craniectomy, referred to by Charlier, it does not exist. Sawing the skull was widely practised even in Italy $[7,8]$. Only one book speaks of the "art of the Italians", by Reynar Solenander a German archiater, who wrote Consiliorum medicinalium. But craniectomy is recommended.

Yet, Alexandre Lenoir testifies, about the 1793 profanations: "The body of this prince [Henry IV] was so well preserved that the lines of his face were unchanged. He was laid down in the passage of low chapels, wrapped into his shroud, which was also preserved. Everybody could see him until Monday 14th in the morning; he was brought into the choir, at the bottom of the sanctuary's steps, where he remained until 2 pm, and he was taken to the cemetery of de Valois, then into a large grave dug down on the right, on the North side. This cadaver, considered as a dry mummy, had a sawn skull, and contained, instead of the brain which had been removed, tow, oiled with a liquor made of herbs, which spread a strong smell, no one could stand $[7,8,17]$."

Another witness of the exhumation is the playwright Georges Duval who published his Souvenirs de la Terreur de 1788 à 1793 in 1841-1842. He was 16 during the profanations of Saint-Denis. In his memoirs, he especially recalls: "...Besides, the body had been perfectly preserved: the beard spread-out, oiled with perfumes, formed a compact unit, and the lines were so easily recognisable that if the skin had not been the colour of a dry parchment, we could have imagined Henry IV was just asleep. Since the upper part of the skull had been removed, we found a sponge soaked with herbs where the brain should have been and which spread a rather sweet smell $[7,8,18] \ldots "$

We shall bear in mind that Bourdais's skull did not undergo any craniectomy and that it still has its brain.

Argument 19: Deposits of plants in the mouth and in nasal cavities. Embalming using fragrant products [4].

For two centuries, Henry IV's mummy remained locked up into a double leaden and wooden sarcophagus, wrapped into his shroud, stuffed with fragrant products. When his coffin was opened, Alexandre Lenoir asserts: "A very strong odour of herbs was released." During the TV documentary, two famous perfume creators, Mrs Sylvaine Delacourtefrom Guerlain- and Mr Jean-Michel Duriez- from Jean Patou/Rochasare sent to smell the skull. The results were not convincing because the head simply smells of leather, with no "odour of spices, herbs, or balms". The IFF society-International Flavors \& Fragrances Inc.-which has laboratories in Neuilly-sur-Seine, France, performed an organic molecular analysis of the mummy. After passing through the particle detector, the chemist Dominique Favier, expert in fragrances and flavours, confirms the absence of herbal substances which are evidences of embalming. In the documentary, Charlier concludes: "So, a priori, this head has not been embalmed, or this is a natural, spontaneous mummification. It complicates the identification, since this is not a classic reference." Further, Charlier adds: "When we examine with a fiberscope through both nasal cavities, we realize there is no grain of pepper for instance, there is no metallic residues, and there is no herbal residues or whatever $[7,8]$." 


\section{Argument 20: Imprint of bandages [4].}

Alexandre Lenoir had painted Henry IV, once rid of his "bandages". Is it an evidence to identify Bourdais's skull as Henry IV's? Many mummies had had bandages; besides, the existence of an "imprint" should be confirmed. [9].

Argument 21: Presence of residues from a former mould on the face, evidence of a funerary mask [4].

The custom of a funerary mask is classic for royal funerals. Several masks are made in wax or plaster for Henry IV's mask. The oldest seems to be the one from Saint-Geneviève's library. These moulds shall not be mixed up with the different wax representations made by sculptors, related to the model of the deceased king on his coffin during the public exhibition until he was transferred to Saint-Denis. In the $\mathrm{XX}^{\text {th }}$ century, Joseph Emile Bourdais would have made a mask on this skull to try to obtain a result close to Henry IV's. Before, this mummified skull would have been used as an anatomical model for the sculptor Emma NalletPoussin. This argument has lost all credibility $[7,8]$.

Argument 22: Section at the neck using a blade (beheading in 1793) [4].

The testimonies brought together here show that everything that surrounded the remains of Henry IV since the opening of his coffin (October $12^{\text {th }}, 1793$ ) until he was placed into a common grave (October 14 th) occurred in the presence of a large audience. In such conditions, at what point could the head be taken? And by whom? No testimony $[7,8,17]$.

Argument 23: Genetic profile related to Louis XVI's blood (STR, Y chromosome, 6 loci). Direct patrilineal relationship between Henry IV and Louis XVI over 7 generations [4].

In 2010, Philippe Charlier conducts a first study. He cut a fragment of muscle at the extremity of he mummy's neck, as well as fibres of the dry finger preserved at Tavet-Delacour museum in Pontoise, France. Besides, he samples epithelial appendages on the relic of Vivant-Denon in Châteauroux, France, and others preserved in Pau's museum, whose origins are more uncertain. Three control elements with no relation with Henry IV are included: hair from an Egyptian mummy, pleura from a XIII ${ }^{\text {th }}$ century anatomical preparation, and a piece of cotton stained with blood used to wipe off a guillotine's blade in the XIX ${ }^{\text {th }}$ century. The analyses are performed by twice, by the Forensic Institute of the Medicine University of Strasbourg, and again by the Centre of Geogenetic at the Natural History Museum of Denmark at the University of Copenhagen. The result is disappointing. The geneticists did not find any exploitable DNA $[7,8]$.

For his second study in 2012, Charlier gets a sample from "the depth of the person's throat" to compare it to the dried blood of Louis XVI and which would have been taken at the bottom of the king's scaffold, on January $21^{\text {st }}, 1793$. The analysis is performed this time by the Catalan team of Professor Carles Lalueza-Fox from Barcelona, Spain. On December 31 $1^{\text {st }}, 2012$, an article published in Forensic Science asserts a correspondence has been made between the Y chromosome of Bourdais's skull and the Y chromosome of the blood assumed to be Louis XVI's [2].

Doctor Olivier Pascal, expert in genetic profile, licensed by the Cour de Cassation and president of the French Institute of Genetic Profile, and Professor Jean-Jacques Cassiman, professor emeritus from the Catholic University of Louvain, Belgium, will both react as follows to $[7,8]$. Here are Professor Cassiman's conclusions:
"A recent publication showed a resemblance between the $Y$ chromosome from the mummified head and the $Y$ chromosome from the blood sampled from the flask. The immediate conclusion was to authenticate, with this result, both the head and the blood. The first difficulty comes from the absence of a completely reliable reference. Neither the head, nor the blood can be authenticated. The evidences coming from historical researches cannot constitute alone reliable evidences. So it is very surprising that from two unknown factors, the researchers could find two certainties only because coincidentally one genetic profile matched. In mathematics, solving a 2-unknown equation requires to have at least two equations containing both unknowns, which is not the case here. The second difficulty comes from the scientific results themselves. First of all, because of the support used for comparison, $Y$ chromosome. The reliability of forensic identification relies on the characterisation of nonsexual chromosomes, the identification through $Y$ chromosome being reserved for special cases. $Y$ chromosome's characteristics are shared by everyone from a same paternal line, but also by persons who have to familial lineage. Y chromosome is not specific for a person but for a group of persons. It means the correspondence, if it is asserted, could reveal a relationship through the paternal line or be due to chance. Besides, the results published in the international journal are surprising. The tables show that $Y$ chromosome could only be partially characterised for the head and that there are two differences between the Y chromosome from the head and the Y chromosome from the blood, which scientifically mean there is no correspondence between these two chromosomes Y. If it was in a criminal file, such results would not prove the involvement of a person. Given all these arguments, it would be presumptuous to assert the head belongs to Henry IV and the blood to Louis XVI $[7,8]$."

Doctor Pascal adds: "The DNA used for comparison could have been from variable regions of the $Y$ chromosome. Yet, several persons in the general population can have the same Y chromosome without being related. Besides, the study determined only 7 alleles (alternate forms of a gene), among which 2 are different from the blood alleged to belong to the descendant of Henry IV. In our daily practice for criminal cases, these two differences are enough to exclude any family relationship through the paternal line. Even if the identity would be perfect between the DNA from the blood's Y chromosome and the DNA from the skull's Y chromosome, it would be impossible to assert the blood belongs to Louis XVI and the skull to Henry IV, without reference element [7,8]."

The mitochondrial DNA from Bourdais's head was thus determined. If it is Henry IV, it should correspond to the mitochondrial DNA of his feminine relatives. After an in-depth genealogy study, a matrilinear line was determined, ending with the Empress Maria Theresa and to the current Queen Anne of Romania. Her mtDNA has been established for a study on the false dauphin Naundorff (1998). After comparing both mtDNA, Professor Cassiman concluded: "Those carrying this DNA cannot be relatives $[7,8]$."

To check the validity of the conclusions in the 2012 article, Philippe Delorme and Jean-Jacques Cassiman decided to perform complementary analyses. In order to establish the true $\mathrm{Y}$ chromosome of Bourbons- and more generally of the agnatic line coming from Hugh Capet- they contacted three princes directly descending from Henry IV. In order to have the most significant possible result, those selected belonged to branches very remote from one another, in the great Capetian tree. Thus, they obtained the participation of princes SixtusHenry and Axel of Bourbon-Parma- from Louis XIV through Philip $\mathrm{V}$ of Spain on one hand-, and of the prince João Henrique of OrléansBraganza on the other hand, from the younger brother of Louis XIV, Philippe d'Orléans, and thus from the King Louis-Philippe I on the 
Citation: Xavier R, Philippe D, Geoffroy LG (2014) Discussion Surrounding the Identification of Henry IV's Alleged Skull. J Forensic Res 5: 212. doi:10.4172/2157-7145.1000212

Page 7 of 7

other hand. The analyses performed on these three princes conclude that their $\mathrm{Y}$ chromosomes correspond and that they share a relatively close ancestor. If we look at the official family tree of the Bourbons, we see the first common ancestor to our three princes in the paternal line is the King Louis XIII who died in 1643. This analysis does not confirm with absolute certainty they are heirs of Louis XIII but that their respective ancestors: Louis XIV and Philippe d'Orléans had the same father. Thus, that the mother of these latter, Anne of Austria, conceived them with the same father, King Louis XIII. Yet, the DNA signature established from the alleged blood of Louis XVI is completely different from the one found by Professor Cassiman's team. Thus, the blood does not belong to Louis XVI, who had necessarily the same Y chromosome as the other male persons of his lineage. Then, comparing this blood to the alleged head of Henry IV makes no sense, and could lead to the identification of Bourdais' skull [19].

\section{Research hypotheses}

According to Mrs Evelyne Peyre from the Musée de l'Homme, to identify or not this skull, several anthropologists should be gathered as a commission, to compare their results. Studying the lumps on a skull, when fights were frequent, can provide answers. When studying the texts relating the life of Henry IV, could there be a means to develop our knowledge of potential traumas which may have occurred on Henry IV's head during his rides for war? This topographic study would help archive the potential traumas and then a comparison could be performed with the marks on the alleged head of Henry IV [20].

To control the relevance of Capetians' Y chromosome, it may be useful to perform a new analysis on Louis XVII's heart, preserved in Saint-Denis, on whom only mitochondrial DNA was sampled. Still in Saint-Denis, we could consider a DNA analysis of the alleged heart of Louis XIII (probably saved by a painter during the Revolution), as well as of the remains of Louis XVIII, brother of Louis XVI, of the duke of Berry his nephew, of the little Louis d'Artois, stillborn in 1818, or of the last princes of Condé, of Louis VII the Young, or even of the indistinct remains of the Capetian lineage, placed into two large coffins inside the Bourbons' crypt.

\section{Conclusion}

This identification was presented as "formal", from the so-called "undeniable" evidences, with a lot of mass media intervention. In the end, in no case can we talk of evidences, these are mere presumptions or elements of evidence, all questionable, especially regarding historical texts, clearly neglected by Philippe Charlier and Stéphane Gabet. Thus, this is not an identification. This topic must be dealt with with considerable caution, especially as many authors consider this skull as coming from "a natural mummy [7,8]". However, though this skull is very unlike Henry IV's, further investigations should be pursued, especially since there seem to be other possibilities which might give very successful results.

\section{References}

1. Charlier $P$ (2010) Multidisciplinary medical identification of a French king's head (Henri IV) in British Medical Journal 341: c6805.

2. Charlier P, Olalde I, Solé N, Ramírez O, Babelon JP, et al. (2013) Genetic comparison of the head of Henri IV and the presumptive blood from Louis XVI (both Kings of France). Forensic Science International 226: 38-40.
3. Charlier P (2011) La tête momifiée d'Henri IV. Une identification médico-légale. La Revue du praticien 60: 1474-1477.

4. Charlier P, Gabet S (2013) Henri IV, l'énigme du roi sans tête, Vuibert (éd.), Paris.

5. Anonyme (2012) La caisse d'ossements royaux d'Alexandre Lenoir. in L'Histoire.

6. Heroard J (1989) Journal de Jean Héroard, Fayard (éd.), Paris : 1601-1628.

7. Delorme P (2013) Henry IV's wrong head, counter-enquiry on a so-called discovery. Frédéric Aimard \& Yves Briend (ed.), Paris.

8. Duval G (1841-1842) Recollections of the Terror from 1788 to 1793 . Werdet, Paris.

9. Guillemeau J (1612) The surgical works of Jacques Guillemeau, ordinary surgeon of the king and jury member in Paris. With the portraits and figures of all the parts of the human body, \& the required instruments of a surgeon. Treaties and lessons by Mr Germain Courtin, doctor of medicine at Nicolas Buon's, Mount Saint Hilaire, Image Saint Claude, Paris.

10. Heroard J (1989) Jean Héroard's diary, Fayard (eds.), Paris, (re-edition of the diary from 1601 to 1628$)$.

11. Larmuseau MHD, Delorme P, Germain P, Vanderheyden N, Gilissen A, et al. (2013) Genetic genealogy reveals true $Y$ haplogroup of House of Bourbon contradicting recent identification of the presumed remains of two French Kings. European Journal of Human Genetics.

12. Lenoir A (1803) Museum of French monuments: history of glass painting and description of ancient and modern stained glasses to serve Art history, regarding France; decorated with engravings, and notably those about the fable of Cupid and Psyche, according to Raphael's drawings, Guilleminet printing works, Paris.

13. Malgaigne JF (1841) Ambroise Paré's complete work reviewed and collated on all the editions including the variants, tome III, JB. Baillière, Paris.

14. Peyre E (2013) Gathered statements during the Congress of the International Society of human biometrics which took place on July $4^{\text {th }} 2013$, Paris.

15. Pigray(1612) Epitome præceptorum medicinæ chirurgiæ, Regis Chiriatro, \& Scholæ Parisiensis Decanoremediorum expositione.

16. Riaud X (2011) Odontological chronicles of the kings of France and of the Napoleon dynasty, L'Harmattan (edn), Medicine throughout centuries collection, Paris.

17. Anonyme (2012) Alexandre Lenoir's box of royal bones. L'Histoire

18. Archives Des Pyrenees Atlantiques (sans date) - B63; B2398, 2452, 2456, 2458; B2537, Basses-Pyrénées.

19. Beauthier JP (2008) Treaty of legal medicine. Éditions de Boeck Université, Bruxelles.

20. Babelon JP (1982) Henri IV, Fayard (éd.), Paris. 